\title{
The Effect of LRP-1 Gene and Mir-205 on Cardiovascular Disease in Iraqi Patients with Familial Hypercholesterolemia
}

\author{
${ }^{1}$ Zinah A. Ghareeb*, ${ }^{1}$ Hiba M. Abdel-Hassan AlKhafaji, ${ }^{2}$ Mohanad K. Aneed Al-Saedi \\ ${ }^{1}$ Department of Applied Sciences, University of Technology, Iraq \\ ${ }^{2}$ Iraqi Hereditary Company, Iraq
}

Article information

Article history:

Received: May, 26, 2021

Accepted: July, 08, 2021

Available online: September, 18, 2021

Keywords:

Familial hypercholesterolemia,

$L R P-1$ gen,

Mir-205 gene,

Cardiovascular disease

Corresponding Author:

Zinah Abdulkareem Ghareeb

80210@uotechnology.edu.iq

\begin{abstract}
Familial hypercholesterolemia (FH) is a genetic disorder characterized by autosomal inheritance in genes related to LDL-C metabolism, with the major clinical features of hyper-LDL-cholesterolemia and premature coronary artery disease. (LRP-1) is a member of the LDLR family. It is a membrane receptor with scavenging and signaling properties. LRP-1 interacts with a wide range of extracellular ligands as well as intracellular scaffolding and signaling proteins, which makes it important in crucial clinical circumstances like cardiovascular disease, cancer, and neurological illnesses. Mir-205 uses these molecules as biomarker for cardiovascular diseases. This study aims to measure gene expression for the LPR-1 gene and its relationship to the development of cardiovascular disease in familial hypercholesterolemia and nonfamilial hypercholesterolemia. Also, it studies the indication whether mir-205 regulates the action of the LRP-1 gene in terms of increasing or decreasing gene expression. However, the available methods for measuring LRP1 levels are direct and quantitative using Poly Chain Reaction (RT-PCR) in real time, not at its ends. In the present study, blood was isolated from 150 individuals distributed into three groups: Group 1 included: 50 samples from a healthy group; Group 2: 50 samples from nonFamilial hypercholesterolemia patients; Group 3:50 samples Familial hypercholesterolemia patients. The results showed that LRP1 protein expression was significantly reduced in patients with F.H compared with normal control in a small cohort from an Iraqi population. This pilot study suggests that the reduced LRP1 protein expression may be associated with cardiovascular disease progression.
\end{abstract}

DOI: 10.53293/jasn.2021.3691.1036, Department of Applied Science, University of Technology

This is an open access article under the CC BY 4.0 License

\section{Introduction}

Familial hypercholesterolemia is a term used to describe a group of inherited and acquired illnesses in which the body's lipid levels are abnormally high [1]. Generally, hypercholesterolemia does not have any obvious symptoms but they are usually discovered during a routine examination or until it reaches the danger stage of a stroke or heart attack [2]. Primary (familial) hypercholesterolemia and secondary (acquired) hypercholesterolemia are the two types of hypercholesterolemia. Primary hypercholesterolemia is caused by a variety of genetic disorders that a patient can inherit at birth. In contrast, secondary hypercholesterolemia is caused by a different underlying cause: poor diet, medications (amiodarone, glucocorticoids), hypothyroidism, uncontrolled diabetes, and/or a poor lifestyle regimen [3, 4]. Cholesterol is an important building block in the formation and repair of cell walls, a function of nerve tissue, and the production of hormones such as testosterone, estrogen, and the stress hormone cortisol [5, 6]. In adults, hypercholesterolemia has been shown to be a major risk factor in developing CVD [7]. 
Genes are nucleotide sequences in DNA or RNA that code to produce a gene product, such as protein [8]. Low-density lipoprotein receptor-related protein-1 (LRP-1) is a member of the LDLR family. It scavenges and signals actions that are shared by a membrane receptor. LRP-1 interacts with a wide range of extracellular ligands as well as cytoplasmic scaffolding and signaling proteins, making it important not just in essential pathological situations including cardiovascular disease, cancer, and neurological disorders, but also in everyday life [9, 10]. MicroRNA 205 (miR205 ) is a well-known miRNA that regulates various biological processes including, cell survival, death, angiogenesis, and metastasis [11].

Gene expression is the process of using a gene's genetic code, or nucleotide sequence, to produce a functioning gene product. It entails a series of stages in which DNA is transformed into RNA then transformed into a protein [12]. Many studies focused on the role of the LRP1 gene and mir-205 in association with cardiovascular disease by using RT PCR $[13,14]$. Ischemic heart disease (myocardial infarction, angina) and stroke are both caused by narrowed or blocked (thrombosis) blood arteries, which can lead to ischemic heart disease (IHD) (myocardial infarction, angina) or stroke. This makes it impossible for blood to reach the heart or the brain. The most common cause is a thrombus (clot) that arises when fatty deposits on the inner walls of blood vessels pool and obstruct the arteries. Blood clots or bleeding from a blood artery in the brain can cause strokes $[15,16]$. Our study aimed at measuring gene expression for the $L R P$ $l$ gene and its relationship to the development of cardiovascular disease in familial hypercholesterolemia and screening for cardiovascular disease using mir-205 as a biomarker specific and sensitive for the LRP-1 gene. However, it is worthy to mention that, this study is the first in Iraq, which tackles the effect of mir-205 on the lrp- 1 gene and affect the genes on patients with familial hypercholesterolemia.

\section{Methods and Materials}

This study was taken place during the period from October 2020 to May 2021. All the study experiments were performed at the University of Technology and Iraqi Hereditary company (IHC) [17].

\subsection{Study Group}

The total number of participants in the study was 150 individuals [18]. The samples were taken randomly according to presence of patients in the place, study groups included the following: -

Group 1: Fifty samples of apparently healthy individuals of both sexes, aged between (30-75 years) were obtained for control.

Group 2: Fifty patients' samples of Iraqi men and women diagnosed with non-familial hypercholesterolemia, aged between (37 and 70 years). The samples were collected at Ibn Al-Nafees Hospital for Cardiovascular Medicine and Surgery in Baghdad/Iraq.

Group 3: Fifty patient's samples of Iraqi men and women diagnosed with familial hypercholesterolemia, aged between (30-70 years) the samples were collected at Ibn Al-Nafees Hospital for Cardiovascular Medicine and Surgery in Baghdad/Iraq.

\subsection{Blood Sampling}

From each participant, $2 \mathrm{ml}$ of whole blood was needed to be collected from the venous blood directly into an EDTA containing tube, this procedure was done under sterile conditions [19].

\subsection{Total RNA Extraction with Trizol}

The RNA extraction from the whole blood of both patient and healthy control with TRIzol subjects using protocol in EasyPure ${ }^{\circledR}$ TransZol Up plus RNA kit (Cat. No.: ER501). TRIzol Lysis Reagent was added after the samples were taken. To separate the aqueous phase, chloroform was added to the lysate. After that, the samples were vortexed, incubated for 3 minutes at room temperature, and centrifuged for 15 minutes at 10,000 rounds per minute. To create adequate binding conditions for all RNA molecules, ethanol was added to the separated aqueous phase. After that, samples were eluted in RNase-free water and kept at $-20{ }^{\circ} \mathrm{C}$ until further processing [20]. 


\subsection{MiRNA Extraction from Whole Blood}

The miRNA extraction from whole blood of both patient and healthy control is collected by using the protocol in EasyPure ${ }^{\circledR}$ miRNA kit (Cat. No.: ER601). First, Lysis Buffer10 (LB10) was fully added to the blood mix. Incubate for 5 minutes at room temperature. Then, for the previous components, chloroform was added. Shake the tube briskly by hand for 3 minutes at room temperature, then centrifuge the sample for 15 minutes at 10,000rpm. To create optimal binding conditions for all miRNA molecules, ethanol was added to the separated aqueous phase. After that, miRNA was eluted in RNase-free water and kept at $20^{\circ} \mathrm{C}$ until further processing [21].

\subsection{Primers}

The primers designed in this research are obtained using bioinformatics program NCBI (national center biotechnology information). The optimum concentration of genes forward and reverse primers were 10 Picoml. Primers used in this study with their sequences are shown in (Table 1).

Table (1): primers used in the study designed by the researchers.

\begin{tabular}{|c|c|}
\hline Primer & Sequence $\left(5^{\prime} \rightarrow 3^{\prime}\right.$ direction $)$ \\
\hline \multicolumn{2}{|c|}{ LRP1 Human qPCR expression Primer } \\
\hline Forward & CAACGGCATCTCAGTGGACTAC \\
\hline Reverse & TGTTGCTGGACAGAACCACCTC \\
\hline \multicolumn{2}{|c|}{ GAPDH Human qPCR expression Primer } \\
\hline Forward & TGAGAAGTATGACAACAGCC \\
\hline Reverse & TCCTTCCACGATACCAAAG \\
\hline \multicolumn{2}{|c|}{ miRNA } \\
\hline MiR205 F.P. & TCCTTCATTCCACCGGAGTCTG \\
\hline miRU6 F.P. & AGAGAAGATTAGCATGGCCCCT \\
\hline MiRNA-universe R.P. & GCGAGCACAGAATTAATACGAC \\
\hline
\end{tabular}

\subsection{Real Time PCR (qRT-PCR)}

qRT-PCR was performed using the strata gene Real-time PCR System (Analytik Jena Technologies) with qPCRsoft software. Gene polymorphism was quantified by probe color reaction employing the 2xqPCR Master Mix Kits components as shown in (Table 2). A non-template control (NTC), non-amplification control (NAC), and nonprimer control (NPC) were included as negative controls for each reaction in duplicate [22].The expression ratio was calculated without a calibrator sample $2-\Delta \mathrm{Ct}$ according to the following:

$\Delta \mathrm{CT}$ (test) $=\mathrm{CT}$ gene of interest (target, test $)-\mathrm{CT}$ internal control

$\Delta \Delta \mathrm{CT}$ was calculated according to the following equation:

$\Delta \Delta \mathrm{CT}=\Delta \mathrm{CT}$ (test)- $\Delta \mathrm{CT}$ (calibrator) 
Table 2. Reaction Component and volume for RT PCR used in LRP-1 gene expression experiment.

\begin{tabular}{|c|c|}
\hline Component & Volume \\
\hline Master mix Syper Green & $10 \mu \mathrm{l}$ \\
\hline Forward primer & $1 \mu \mathrm{l}$ \\
\hline Revers primer & $1 \mu \mathrm{l}$ \\
\hline CDNA & $2 \mu \mathrm{l}$ \\
\hline Nuclease free water (N.F.W) & $6 \mu \mathrm{l}$ \\
\hline Total volume & $20 \mu \mathrm{l}$ \\
\hline
\end{tabular}

\subsection{The qPCR Reaction Run}

The cycling protocol was programmed according to the thermal profile shown in (Table 3).

Table 3. Thermal profile of LRP-1 gene expression.

\begin{tabular}{|c|c|c|c|}
\hline Step & Temperature & Duration & Cycles \\
\hline Enzyme activation & $94^{\circ} \mathrm{C}$ & $30 \mathrm{sec}$ & Hold \\
\hline Denature & $94^{\circ} \mathrm{C}$ & $5 \mathrm{sec}$ & \multirow{2}{*}{40} \\
\hline Anneal & $64^{\circ} \mathrm{C}$ & $15 \mathrm{sec}$ & \\
\hline Extend & $72^{\circ} \mathrm{C}$ & $15 \mathrm{sec}$ & \\
\hline
\end{tabular}

\subsection{Housekeeping Gene Amplification}

Glyceraldehyde 3-phosphate dehydrogenase (GAPDH). As an internal control, the housekeeping gene was employed to calculate the $\triangle \mathrm{CT}$ value [23]. The Thermal profile presented was used in a qPCR experiment for GAPDH amplification (Table 4).

Table (4): Thermal profile of GAPDH gene expression.

\begin{tabular}{|c|c|c|c|}
\hline Step & Temperature & Duration & Cycles \\
\hline Enzyme activation & $94^{\circ} \mathrm{C}$ & $30 \mathrm{sec}$ & Hold \\
\hline Denature & $94^{\circ} \mathrm{C}$ & $5 \mathrm{sec}$ & 40 \\
\hline Anneal & $54^{\circ} \mathrm{C}$ & $15 \mathrm{sec}$ & \\
\hline Extend & $72^{\circ} \mathrm{C}$ & $15 \mathrm{sec}$ & \\
\hline
\end{tabular}

\subsection{Statistical Analysis}

The Statistical Analysis System- SAS (2012) program was used. Least significant difference -LSD test (Analysis of Variation-ANOVA) was used to make significant comparison between means. Chi-square test was used to make a significant comparison between percentage ( 0.05 and 0.01 probability). Estimation of the correlation coefficient between variables in this study is achieved [24]. 


\section{Results and Discussion}

The $\mathrm{Ct}$ value of GAPDH, the housekeeping gene used in this research, is seen in (Table 5). The range of $\mathrm{Ct}$ value for $G A P D H$ in the healthy group was $16.28-18.43$ with a mean \pm SD $(17.68 \pm 0.53)$. It ranged from 17.12-18.43 with a mean \pm SD $(17.70 \pm 0.36)$ for the $\mathrm{H}$ group. The F.H group range from 16.08-18.53 with a mean $\pm \mathrm{SD}(17.71 \pm 0.51)$. A non-significant difference was found between these groups regarding the mean $\mathrm{Ct}$ value of GAPDH, $(\mathrm{p}=0.935$ : $\mathrm{p}<0.05)$ with an LSD value of (0.187).

Table (5): Comparison between the different studied groups in the GAPDH Ct value of (Mean \pm SD).

\begin{tabular}{|c|c|c|c|}
\hline Group & No. & $\begin{array}{c}\text { Mean } \pm \text { SD of Ct } \\
\text { value }\end{array}$ & Range \\
\hline Group 1 Control & 50 & $17.68 \pm 0.53$ & $16.28-18.43$ \\
\hline Group 2 Hypercholesterolemia & 50 & $17.70 \pm 0.36$ & $17.12-18.43$ \\
\hline Group 3 & 50 & $17.71 \pm 0.51$ & $16.08-18.53$ \\
\hline Familial Hypercholesterolemia & -- & $0.187 \mathrm{NS}$ & --- \\
\hline PSD & -- & 0.935 & -- \\
\hline
\end{tabular}

The inherent assumption in using housekeeping genes in molecular studies is that their expression remains constant in the cells or tissue under investigation. One of the most commonly used housekeeping genes in the companion of gene expression data is GAPDH [25]. Studying the expression of 1,718 genes using qRT-PCR, the GAPDH has been applied as a reference gene in 72 kinds of normal human tissue. It has been found out that using GAPDH is quite a reliable strategy for the normalization in qRT-PCR when applied in clinical studies. To improve this, the variance of the total change in GAPDH expression was analyzed in different study groups using the $2^{-\mathrm{Ct}}$ value and the ratio of $2^{-\mathrm{Ct}}$ of the different study groups to that of the control group, as shown in (Table 6). The $2^{\text {-Ct }}$ value of the healthy group was 4.681E-06. For the $\mathrm{H}$ group, it was 4.755E-06 and for the F.H group it was 4.645E-06. The computed ratio for gene fold expression was $1.00 \pm 0.00$ for the healthy groups, $1.0159 \pm 0.04$ for the $\mathrm{H}$ group and $0.992 \pm 0.04$ for the F.H group. The results show differences in CT values low for $\mathrm{H}$ group and morelower for F.H group. Our findings are also in line with those of this study [26, 27], which looked at the possible association of the LRP-1 gene with genetic damage, hypercholesterolemia, and familial hypercholesterolemia risk.

Table (6): Comparison of GAPDH Fold Expression between Control, H and F.H groups.

\begin{tabular}{|c|c|c|c|c|}
\hline Group & Means Ct of & 2-Ct & $\begin{array}{c}\text { Experimental group/ } \\
\text { Control group }\end{array}$ & $\begin{array}{c}\text { Fold of gene } \\
\text { expression }\end{array}$ \\
\hline Group 1 C. & 17.7048 & $4.681 \mathrm{E}-06$ & $4.681 \mathrm{E}-06 / 4.681 \mathrm{E}-06$ & $1.00 \pm 0.00$ \\
\hline Group 2 H. & 17.682 & $4.755 \mathrm{E}-06$ & $4.755 \mathrm{E}-06 / 4.681 \mathrm{E}-06$ & $1.0159 \pm 0.04$ \\
\hline
\end{tabular}




\begin{tabular}{|c|c|c|c|c|}
\hline Group 3 F.H. & 17.7158 & $4.645 \mathrm{E}-06$ & $4.645 \mathrm{E}-06 / 4.681 \mathrm{E}-06$ & $0.992 \pm 0.04$ \\
\hline LSD value & -- & -- & -- & $0.263 \mathrm{NS}$ \\
& \multicolumn{5}{|c|}{ NS: Non-Significantly. } \\
\hline
\end{tabular}

In this study, a quantitative RT-PCR technique was used to examine the LRP-1 mRNA expression and compare it to that of the seemingly healthy control group, the H group, and the F.H group. The fold change in gene expression was calculated using relative quantification. This is dependent on the normalization of $\mathrm{Ct}$ values when calculating the $\Delta \mathrm{Ct}$, which is the difference between the mean $\mathrm{Ct}$ values of each case's replica of LRP-1 cDNA amplification and the GAPDH. The result of each group's $2^{-\Delta \mathrm{Ct}}$ was compared to that of the control group to determine the gene expression folds in respect to the housekeeping genes. (Table 7) displays the results. In group $\mathrm{H}$, the gene expression fold was half that of the healthy group. It was much lower $(0.1)$ in the F.H group than it was in the healthy group. The expression of the LRP-1 gene in these populations was found to be significantly lower.

Table (7): Fold of LRP1 expression Depending on 2- ${ }^{\Delta \mathrm{Ct}}$ Method.

\begin{tabular}{|c|c|c|c|c|c|c|}
\hline groups & $\begin{array}{l}\text { Means } \\
\text { Ct of } \\
L R P 1\end{array}$ & $\begin{array}{c}\underset{\text { Means Ct }}{\text { of }} \\
\text { GAPDH }\end{array}$ & $\begin{array}{c}\mathrm{CCt} \text { (Means } \\
\mathrm{Ct} \text { of } L R P 1 \\
-\begin{array}{c}\text { Means } \mathrm{Ct} \\
\text { of }\end{array} \\
\text { GAPDH) }\end{array}$ & $2-{ }^{\Delta \mathrm{Ct}}$ & $\begin{array}{l}\text { Experimental } \\
\text { group/ Control } \\
\text { group }\end{array}$ & $\begin{array}{c}\text { Fold of gene } \\
\text { expression }\end{array}$ \\
\hline Group 1 Control. & 26.36 & 17.7 & 8.66 & 0.0024722 & $0.00247 / 0.00247$ & $1.00 \pm 0.00 \mathrm{a}$ \\
\hline Group $2 \mathrm{H}$. & 27.17 & 17.68 & 9.49 & 0.0013907 & $0.00139 / 0.00247$ & $0.5625 \pm 0.06 \mathrm{~b}$ \\
\hline Group 3 F.H. & 29.16 & 17.71 & 11.45 & 0.0003574 & $0.00035 / 0.00247$ & $0.14459 \pm 0.08 \mathrm{c}$ \\
\hline LSD value & -- & -- & -- & -- & -- & $0.278 * *$ \\
\hline \multicolumn{7}{|c|}{$* *(\mathrm{P} \leq 0.01)$} \\
\hline
\end{tabular}

The calculation of the relative expression of the LRP-1 gene in all study groups was achieved by applying the $2-\Delta \Delta \mathrm{Ct}$ results. A calibrator used was one of the samples of the controls with low expression of LRP-1. As shown in (Table $8)$, the mean of $2-\Delta \Delta C t$ values of the Healthy group, H group and F.H group it $(0.2191),(0.1232)$ and $(0.0316)$, respectively. Thus, there was a significant difference between these groups regarding the mean $2-\Delta \Delta \mathrm{Ct},(\mathrm{p} \leq 0.01)$. We hypothesize that microRNA, known for gene silencing either through mRNA degradation or translation repression, may contribute in the down-regulation of LRP1 expression, as one microRNA, miR-205, has been reported to regulate LRP1. This miR-205 has been found to suppress LRP1 expression by limiting the translation of LRP1 mRNA into proteins without changing the mRNA level, which is consistent with our findings of lower LRP1 protein expression. As a result, it is thought that miR-205 is overexpressed in the cardiovascular system, suppressing LRP1 translation and lowering LRP1 protein levels [28]. 
Table (8): Fold of LRP1 expression Depending on 2- $\Delta \Delta$ Ct Method.

\begin{tabular}{|c|c|c|c|c|c|c|c|c|}
\hline Groups & $\begin{array}{l}\text { Means } \\
\text { Ct of } \\
\text { LRP1 }\end{array}$ & $\begin{array}{c}\text { Means } \\
\text { Ct of } \\
\text { GAPDH }\end{array}$ & $\begin{array}{c}\Delta \mathrm{Ct} \\
\text { (Means } \\
\text { Ct of } \\
\text { LRP1 } \\
\text { - Means } \\
\text { Ct of } \\
\text { GAPDH } \\
\text { ) }\end{array}$ & $\begin{array}{c}\text { Mean } \\
\Delta C t \\
\text { Calib } \\
\text { rator } \\
\text { (ct } \\
\text { LRP1 } \\
\text {-ct } \\
G A P \\
D H\end{array}$ & $\Delta \Delta \mathbf{C t}$ & $\begin{array}{c}2- \\
\Delta \Delta C t\end{array}$ & $\begin{array}{l}\text { Experimental } \\
\text { group/ Control } \\
\text { group }\end{array}$ & $\begin{array}{c}\text { Fold of } \\
\text { gene } \\
\text { expression }\end{array}$ \\
\hline Group $1 \mathrm{C}$. & 26.36 & 17.7 & 8.66 & 6.47 & 2.19 & 0.2191 & $0.2191 / 0.2191$ & $1.00 \pm 0.00 \mathrm{a}$ \\
\hline Group 2 H. & 27.17 & 17.68 & 9.49 & 6.47 & 3.02 & 0.1232 & $0.1232 / 0.2191$ & $\begin{array}{c}0.5625 \\
\pm 0.06 \mathrm{~b}\end{array}$ \\
\hline $\begin{array}{c}\text { Group } 3 \\
\text { F.H. }\end{array}$ & 29.16 & 17.71 & 11.45 & 6.47 & 4.98 & 0.0316 & $0.0316 / 0.2191$ & $\begin{array}{l}0.14459 \\
\pm 0.08 \mathrm{c}\end{array}$ \\
\hline LSD value & -- & -- & -- & -- & -- & -- & -- & $0.278 * *$ \\
\hline
\end{tabular}

\section{Conclusions}

The expression of the LRP-1 gene was found to be a helpful marker in the prediction of cardiovascular disease. Furthermore, the significant connection between LRP-1gene and mir-205 suggests that this biomarker may play a role in the pathophysiology of atherosclerotic coronary artery disease (ASCAD) and could be used as a valid diagnostic and therapeutic marker.

\section{Acknowledgements}

We sincerely thank the faculty and staff members at the Institute of Applied Science Department / Biotechnology division / University of Technology and Iraqi Hereditary Company (IHC) and staff members at Ibn Al-Nafees Hospital for Cardiovascular Medicine and Surgery in Baghdad/Iraq.

\section{Conflict of Interest}

The authors declare that they have no conflict of interest.

\section{References}

[1] M. F. Hill and B. Bordoni, "Hyperlipidemia," StatPearls, 2020.

[2] G. F. Shattat, "A review article on hyperlipidemia: types, treatments and new drug targets," Biomedical and Pharmacology Journal, vol. 7, no. 1, p. 399-409, 2015.

[3] T. Richardson, S. Aslibekyan, and A. P. Ashraf, "Clinical Characteristics and Sequelae of Severe Hypertriglyceridemia in Pediatrics," Endocrine Practice, vol. 24, no. 9, p. 789-795, 2018, doi: https://doi.org/10.4158/EP-2018-0106.

[4] D. S. Wald, J. P. Bestwick, J. K. Morris, K. Whyte, L. Jenkins, and N. J. Wald, "Child-parent familial hypercholesterolemia screening in primary care," N Engl J Med, vol. 375, p. 1628-1637, 2016.

[5] M. Shikara, H. M. Al-Khafagi, and W. H. Mohammed, "Extraction and Characterization of A Chromosomal Stain From Black Mulberry (Morus Nigra)," Engineering and Technology Journal, vol. 28, no. 7, 2010.

[6] R. Verma, "REVIEW ARTICLE ON HYPERCHOLESTEROLEMIA," International Journal of Current Research, 2020, doi: 10.24941/ijcr.38625.05.2020.

[7] J. Stewart, T. McCallin, J. Martinez, S. Chacko, and S. Yusuf, "Hyperlipidemia," Pediatr Rev, vol. 41, no. 8, p. 393-402, 2020.

[8] R. C. Elston, J. M. Satagopan, and Sh. Sun, “Statistical Human Genetics,” Springer, 2012. 
[9] E. S. Stroes et al., "Statin-associated muscle symptoms: impact on statin therapy-European Atherosclerosis Society consensus panel statement on assessment, aetiology and management," European heart journal, vol. 36, no. 17, p. 1012-1022, 2015.

[10] B. Kamal and N. Al-Saidi, "Extended Chaotic Nonlinear Programming Technique Constructing with Genetic Algorithms," Journal of Applied Sciences and Nanotechnology, vol. 1, no. 1, p. 15-22, 2021, doi: 10.53293/jasn.2021.11018.

[11] E. Ferrari and P. Gandellini, "Unveiling the ups and downs of miR-205 in physiology and cancer: transcriptional and post-transcriptional mechanisms," Cell Death \& Disease, vol. 11, no. 11, p. 1-10, 2020.

[12] C. Buccitelli and M. Selbach, "mRNAs, proteins and the emerging principles of gene expression control," Nature Reviews Genetics, vol. 21, no. 10, p. 630-644, 2020.

[13] H. Al-Khafaji, "Gene Expression Bcl-2 Gene in Cancer of Brest in Iraqi population," Engineering and Technology Journal, vol. 35, no. 2 Part B, p. 119-125, 2017.

[14] D. P. Bartel, "MicroRNAs: genomics, biogenesis, mechanism, and function," cell, vol. 116, no. 2, p. 281-297, 2004.

[15] B. Wong, G. Kruse, L. Kutikova, K. K. Ray, P. Mata, and E. Bruckert, "Cardiovascular disease risk associated with familial hypercholesterolemia: a systematic review of the literature," Clinical therapeutics, vol. 38, no. 7, p. 1696-1709, 2016.

[16] B. Jasim and E. Ali, "Enhanced Production of Fibrinolytic Enzyme from Pseudomonas aeruginosa by Optimization Media Components," (in en), Journal of Applied Sciences and Nanotechnology, vol. 1, no. 2, p. 5865, 2021, doi: 10.53293/jasn.2021.11637.

[17] B. Schuurman, "Research on terrorism, 2007-2016: A review of data, methods, and authorship," Terrorism and Political Violence, vol. 32, no. 5, p. 1011-1026, 2020.

[18] S. A. Abed and H. M. Al-Khafaji, "Design Of Primer And Probe To Detect SNP Rs 1892901 In Fosl-1Gene In Different Types Of Cancer In Iraqi Population," Systematic Reviews in Pharmacy, vol. 12, no. 1, p. 296-300, 2021.

[19] R. Mehmood, R. K. Muhammed, S. Hussain, and A. Sana, "Evaluation of di-potassium and tri-potassium EDTA evacuated tubes for routine haematological testing," Journal of clinical laboratory analysis, vol. 32, no. 1, p. e22188, 2018.

[20] L. Xu et al., "Dioscin, a potent ITGA5 inhibitor, reduces the synthesis of collagen against liver fibrosis: Insights from SILAC-based proteomics analysis," Food and Chemical Toxicology, vol. 107, p. 318-328, 2017.

[21] J. Zhang, Y. Xu, T. Cao, J. Chen, B. P. Rosen, and F.-J. Zhao, "Arsenic methylation by a genetically engineered Rhizobium-legume symbiont," Plant and soil, vol. 416, no. 1, p. 259-269, 2017.

[22] A. Josheghanian, E. Akbari-hamed, E. Khanlarzadeh, M. h. Gholami, and S. Nikzad, "Treatment Outcomes and Survival of Patients with Gastric Cancer in Hamadan, Iran: A Retrospective Study," Journal of Applied Sciences and Nanotechnology, vol. 1, no. 2, p. 16-26, 2021, doi: 10.53293/jasn.2021.3704.1037.

[23] Y. Panina, A. Germond, S. Masui, and T. M. Watanabe, "Validation of common housekeeping genes as reference for qPCR gene expression analysis during iPS reprogramming process," Scientific reports, vol. 8, no. 1, p. 1-8, 2018.

[24] N. Cary, "Statistical analysis system, User's guide. Statistical. Version 9," SAS. Inst. Inc. USA, 2012.

[25] R. D. Barber, D. W. Harmer, R. A. Coleman, and B. J. J. P. g. Clark, "GAPDH as a housekeeping gene: analysis of GAPDH mRNA expression in a panel of 72 human tissues," vol. 21, no. 3, p. 389-395, 2005.

[26] D. T. Au, A. L. Arai, W. E. Fondrie, S. C. Muratoglu, and D. K. Strickland, "Role of the LDL receptor-related protein 1 in regulating protease activity and signaling pathways in the vasculature," Current drug targets, vol. 19, no. 11, p. 1276-1288, 2018.

[27] T. D. Schmittgen and K. J. Livak, "Analyzing real-time PCR data by the comparative CT method," Nature protocols, vol. 3, no. 6, p. 1101-1108, 2008.

[28] C. Chan, Y. Chan, B. Cheuk, and S. Cheng, "A pilot study on low-density lipoprotein receptor-related protein-1 in Chinese patients with abdominal aortic aneurysm," European Journal of Vascular and Endovascular Surgery, vol. 46, no. 5, p. 549-556, 2013. 